\title{
Salıpazarı ve Çevresinde (Samsun/Türkiye) Doğal Olarak Yetişen Bitkilerin Etnobotanik Özellikleri ${ }^{\dagger}$
}

\author{
Esra Demir ${ }^{1}$, Burak Sürmen $^{2 *}$, Harun Özer ${ }^{1}$, Hamdi Güray Kutbay ${ }^{3}$ \\ ${ }^{1}$ Ondokuz Mayıs Üniversitesi, Ziraat Fakültesi, Bahçe Bitkileri Bölümü, Samsun, Türkiye \\ ${ }^{2}$ Karamanoğlu Mehmetbey Üniversitesi, Kamil Özdağ Fen Fakültesi, Biyoloji Bölümü, Karaman, Türkiye \\ ${ }^{3}$ Ondokuz Mayıs Üniversitesi, Fen Edebiyat Fakültesi, Biyoloji Bölümü, Samsun, Türkiye
}

Geliş Tarihi: 16.06 .2017

*Sorumlu Yazar: buraksurmen@gmail.com

Kabul Tarihi: 20.10 .2017

\begin{abstract}
Özet
Bu çalışmada, Samsun Salıpazarı İlçesi ve çevresinde doğal olarak yetişen yenilebilir yabani otlar belirlenmiştir. Çalışma 2015 ve 2016 yıllarında yürütülmüştür. İlk olarak yerel pazarlar daha sonra köylerde yaşayan insanların topladıkları yabani yenilebilir bitkiler araştırılmıştır. 12 familyaya ait 14 tür belirlenmiştir. Ayrıca bu yabani bitkilerin etnobotanik özellikleriyle kullanımını belirlenmiştir. Bunun yanı sıra, yerel isimleri, kullanılan kısımları ve kullanım amaçları tespit edilmiştir. Sonuç olarak alandan toplanan bitki örneklerinin değerlendirilmesiyle yiyecek olarak kullanılan 14 yabani bitki türü tespit edilmiştir.
\end{abstract}

Anahtar Kelimeler: Etnobotanik, Salıpazarı, Yabani bitkiler.

\section{Ethnobotanical Characteristics of Naturally Growing Plants in Salıpazarı and its Environments (Samsun/Turkey)}

\begin{abstract}
In this study, we determined vegetable wild plants which are naturally grown in Samsun Salipazarı Country and its environments. We carried out this study between in 2015 and 2016. Firstly, we visited the county public markets and secondly we researched vegetable wild plants which collected by indigenous people in villages. 14 taxa belonging to 12 families were determined. Usages of the plants which are ethnobotanical features were determined. And it has been listed local names, using parts and using purposes. As a result of the evaluation of the collected plant samples from the area it has been identified as 14 natural plant food is used.
\end{abstract}

Keywords: Ethnobotanic, Salıpazarı, Wild plants.

\footnotetext{
$\dagger^{\dagger}$ Bu çalışmanın bir bölümü International Symposium on Biodiversity and Edible Wild Species'de özet bildiri olarak sunulmuştur.
} 


\section{Giriş}

Dünya'da insan nüfusunun hızla artış göstermesi ile birlikte bitkisel kaynakların bilinçsizce kullanımı, yerel çeşitlerin yerini ıslah sonucu elde edilen yeni çeşitlerin alması, yabancı ot ilaçlarının kullanımı, doğal afetler ve şehirleşme bitki gen kaynaklarının azalmasına ve hızla kaybolmasına sebep olmaktadır (Balkaya ve Yanmaz, 2001; Özgen ve ark., 2004; Civelek, 2011). Bu durum bitki gen kaynaklarının korunması çalışmalarını arttırdı̆̆ı gibi farklı kullanım alanı olan yeni bitki türlerini de ortaya çıkarmaktadır.

Türkiye, fitocoğrafik konumu (Avrupa Sibirya, İran-Turan ve Akdeniz Fitocoğrafik Bölgeleri) nedeniyle bitki gen kaynağı bakımından zengin bir ülkedir. Yaklaşı 12.000 bitki türünün bulunduğu Türkiye, tek başına Avrupa Kıta Florası'na eş bitki çeşitliliğine sahiptir (Kutbay ve ark., 2014). Ayrıca dünya genelinde gıda olarak tüketilen bitkilerin 20 civarında türden elde edildiği bildirilirken, gıda olarak tüketilen yabani bitki bitkilerin sayısının ise 10.000'in üzerinde olduğu rapor edilmiştir (Yücel ve ark., 2011). Türkiye'nin bitki çeşitliği dikkate alındığında, ülkemizde henüz rapor edilmeyen fakat gıda olarak kullanılan birçok yabani bitkinin varlığı kaçınılmazdır.

Son yıllarda tüm dünyada doğal beslenmeye doğru bir eğilim gelişmiştir. Bu eğilimim artması ve hızlı nüfus artışı ile birlikte ortaya çıkan beslenme sorunları karşısında sebze olarak tüketimi yapılan yabani otların önemi artmıştır (Kaya ve İncekara, 2000). Sebze olarak tüketilen yabani sebzelerin besin içeriklerinin birçok kültür sebzesine oranla yüksek olması bu artışa katkı sağlamıştır (Lyimo ve ark., 2003; Civelek, 2011; Kibar ve Temel, 2015). Dolayısıyla bu bitkiler eskiye oranla pazarlarda, manavlarda daha fazla satılmaya başlanmıştır (Kaya ve İncekara, 2000). Bu eğilimin güç kazanması ile dikkatler doğada kendiliğinden yetişen kültüre alınmamış bitkilere de yönelmeye başlamıştır (Altay ve Karahan, 2012). Ülkemizde doğada kendiliğinden yetişen otsu bitkilerin sebze olarak tüketimi oldukça yaygındır. Tüm dünyada olduğu gibi ülkemizde de doğal florada bulunan bitkilerin halk arasında tedavi amaçlı, gıda, çay, bahara vb., olarak kullanımı uzun yıllardan beri süregelen geleneksel kültürel zenginliğimizin bir parçası olmuştur. Ancak bu olgu şehirleşmeyle paralel olarak kaybolmaya başlamıştır (Faydaoğlu ve Sürücüoğlu, 2011).

Yenilebilen yabani bitkilerle ilgili sahip olduğumuz kültürel mirasın korunması ve gelecek nesillere aktarılabilmesi için, tür ve çeşitlerimizin kayıt altına alınması oldukça önemli bir konudur. $\mathrm{Bu}$ konunun hayata geçirilmesi için ise bahsedilen bitkilerin halk tarafindan çeşitli kullanım şekillerinin tespit edileceği etnobotanik çalışmaların ülke genelinde başlatılarak sürdürülmesi gerekmektedir (Kargıoğlu ve ark., 2008; Satıl ve ark., 2008).

Tüm bu sebeplerden dolayı araştırıcıların bu konuya önem vererek gerekli çalışmaları yapmaları oldukça önem arz etmeye başlamıştır. Bu konunun önemini fark eden araştırmacılar faklı bölgelerde çalışmalar yürütmüşlerdir. Fakat Samsun'un Salıpazarı İlçesi’ndeki yenilebilir otların 
belirlenmesi ile ilgili bir çalışma yapılmamıştır. Araştırmanın yürütüleceği Salıpazarı İlçesi, Davis'in belirlemiş olduğu kareleme sistemine göre A6 karesinde ve Avrupa Sibirya Fitocoğrafik Bölgesinin Öksin alt fitocoğrafik bölümünde yer almaktadır. Nüfus yoğunluğu çok fazla olmayan ilçenin kuzey kesimleri düzlük, güneyi ise engebeli yapıya sahiptir. Yeşil Çay ile Terme Çayı ilçe merkezinde kesişmektedir. İklimi açısından Salıpazarı'nı iki kısımda değerlendirmek mümkündür. Ovalık kesimlerde tipik Orta Karadeniz iklimi hâkim olmakla beraber, yazlar serin, kışlar 1lık geçmektedir. Fakat yüksek kesimlere çıkılmaya başlandıkça iklim sertleşir. Kışın 2 m’yi aşan kar yağışı gözlemlenebilir. İlçe arazisinin \%80'i engebeli-dağlık konumda ve son derece gür ve yeşil bir bitki örtüsüne sahiptir. Fındık bahçeleri başta olmak üzere ormanlık alanlarda meşe, kızılağaç, kestane ağaçları yörede büyük yer kaplar. Bunların yanı sıra bu ağaçların arasında çok çeşitli ot ve bitkilere de rastlamak mümkündür (Anonim, 2015).

Sonuç olarak yapılan bu çalışma ile daha önce taranmamış Samsun'un Salıpazarı İlçesi'nde doğal olarak yetişen, halk tarafından sebze olarak tüketilen yabani bitki türleri belirlenerek, tür cins ve familyaları tespit edilmiş, yerel isimleri ve kullanım şekilleri kaydedilmiştir.

\section{Materyal ve Metot}

Bu çalışmada, Salıpazarı ve çevresi (Samsun/Türkiye) araştırma alanı olarak belirlenmiştir. Salıpazarı denize kıyısı bulunmayan yüzölçümü, yaklaşık $16.451 \mathrm{~km} 2$ ve ilçe merkezi ortalama olarak 859.1 m yüksekliğe sahiptir (Şekil 1). Salıpazarı İlçesi'nin Samsun İli’ne uzaklığı ise 54 km’dir. İlçenin güneyinde Erbaa ve Akkuş, doğusunda Terme, batısında Ayvacık, kuzeyinde ise Çarşamba ilçeleri bulunmaktadır. Bu alan içinde yayılış gösteren ve bölge halkı tarafından çeşitli amaçlarla kullanılan yenebilir yabani bitkiler materyal olarak seçilmiştir.

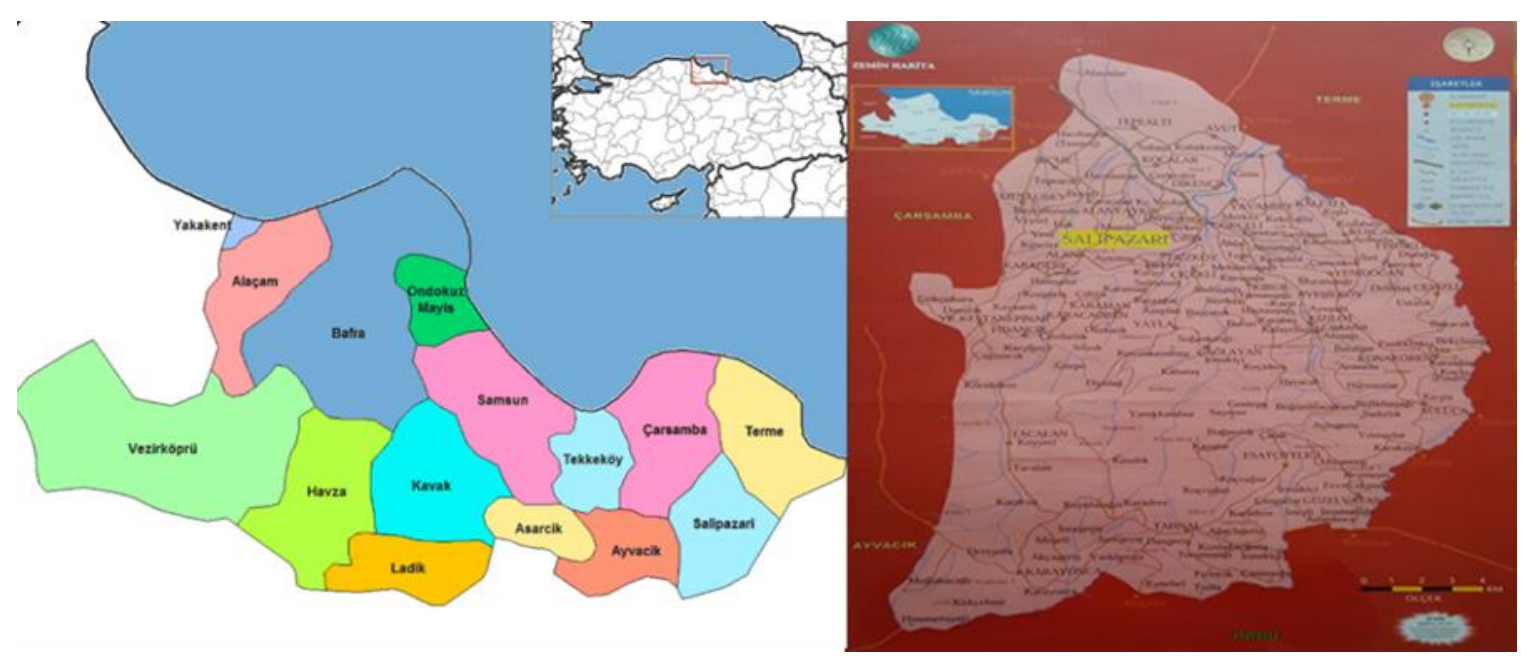

Şekil 1. Giresun Üniversitesi için örnek bir resim. 
Arazi çalışması 2015 - 2016 yıllları arasında yapılmıştır. Bu amaca yönelik olarak öncelikle ilçe halk pazarları gezilmiş ve sebze olarak satışa sunulan yabani otlar tespit edilip bu otların toplandıkları yerler öğrenilmiştir. Sonrasında ilçenin çeşitli köylerinde yaşayan halk ile karşılıklı görüşmeler yapılarak sebzelerin yetiştiği diğer bölgeler belirlenmiştir. Araştırmada incelenecek olan sebzelerin yerel adları, toplanışı ve tüketimi hakkında yeterli bilgi ve tecrübeye sahip kişiler yardımı ile yeteri kadar materyal yöreden toplanmıştır.

Türlerin teşhisi için Flora of Turkey and the East Aegaen Islands (Davis, 1965-1985; Davis ve ark., 1988; Güner ve ark., 2000; Güner, 2012) adlı eserden yararlanılmıştır.

\section{Bulgular ve Tartışma}

Salıpazarı İlçesinde 2015-2016 yılları arasında, ilçenin halk pazarlarında sebze olarak satışa sunulan yabani otların toplandığı köyler belirlenmiştir. Daha sonra alınan bitki örneklerinin değerlendirilmesi sonucunda sebze olarak tüketilen toplam 14 adet bitki türü tespit edilmiştir. Bu bitkilerin yöresel adı, bilimsel adı, familyası, toplandığı yer ile yaşam süresi, hayat formu ve kullanılan kısmı alfabetik sıraya göre Tablo 1'de verilmiştir.

Tablo 1. Salıpazarı'nda sebze olarak tüketilen yabani otlar

\begin{tabular}{|c|c|c|c|c|}
\hline Yöresel Adı & Latince Adı & Familya & Toplandığı Yer & Ömrü ve Formu \\
\hline Civcilik & Stellaria media subsp. media L. & Caryophyllaceae & Kırg1l Köyü & Tek yıllık, otsu \\
\hline Ebegümeci & Alcea apterocarpa Bo1ss. & Malvaceae & Kocalar Köyü & Çok yıllık, otsu \\
\hline Efelek & Rumex crispus L. & Polygonaceae & Salıpazarı merkez & Çok yıllık, otsu \\
\hline Hindiba & Taraxacum buttleri Van Soest & Asteraceae & Muslubey Köyü & Çok yıllık, otsu \\
\hline Isırgan & Urtica dioica $\mathrm{L}$. & Urticaceae & Tepealtı Köyü & Çok yıllık, otsu \\
\hline Kaldırık, Galdirik & Trachystemon orientalis L. & Boraginaceae & Alanyaykın köyü & Çok yıllık, otsu \\
\hline Kazayağı, Gazyek & Oenanthe pimpinelloides L. & Apiaceae & Kırgıl köyü & Çok yıllık, çalı \\
\hline Kırçan, Melocan & Smilax excels L. & Liliaceae & Alanyaykın köyü & Çok yıllık, çalı \\
\hline Medik & Capsella bursa-pastoris L. & Brassicaceae & Kocalar Köyü & Tek yıllık, otsu \\
\hline Mendek & Aegopodium podagraria $\mathrm{L}$. & Apiaceae & Yavaşbey Köyü & Çok yıllık, otsu \\
\hline Nivik & Arum italicum Miller & Araceae & Kırgıl Köyü & Çok yıllık, otsu \\
\hline $\begin{array}{l}\text { Sakarca, } \\
\text { Kuzguncuk soğanı }\end{array}$ & $\begin{array}{l}\text { Ornithogalum sigmoideum Freyn } \\
\text { et. Sint. }\end{array}$ & Liliaceae & Kocalar Köyü & Çok yıllık, otsu \\
\hline $\begin{array}{l}\text { Sirken, Hoşkıran } \\
\text { pancarı }\end{array}$ & Amaranthus retroflexus L. & Amaranthaceae & Kalfalı Köyü & Tek yıllık, otsu \\
\hline Taykuyruğu & Equisetum arvense L. & Equisetaceae & Kocalar Köyü & Çok yıllık, otsu \\
\hline
\end{tabular}

Buna göre 13 tür tohumlu, 1 tür ise (Equisetum arvense L.) tohumsuz bitki türüdür. Yaşam süre tek yıl olan türler Stellaria media subsp. media L., Capsella bursa-pastoris L., Amaranthus retroflexus L. iken diğer türler çok y1llık türlerdir. Hayat formu çalı olan türler ise Oenanthe pimpinelloides L. ve Smilax excelsa iken diğer türlerin tamamı otsu formdadır. Türler toplam 12 familyaya dağılırken bunlardan Apiaceae, Liliaceae familyaları 2 türle diğer familyalar ise 1 türle temsil edilmektedir. 
$\mathrm{Bu}$ çalışmada tespit edilen 14 türden bazıları semt pazarlarında yöre halkı tarafından satılmaktadır. Bunlar Kaldırık (Trachystemon orientalis L.), Kırçan (Smilax excelsa L.) ve Sirken (Amaranthus retroflexus L.) yabani bitkileridir. Diğer 11 tür ise halk tarafindan çevredeki ormanlardan ve açık arazilerden toplandığı tespit edilmiştir. Yenilebilir otların kullanılan kısımları ile yerel halkın bu bitkileri kullanım şekillerine dair bilgiler Tablo 2'de verilmiştir.

Tablo 2. Salıpazarı'nda sebze olarak tüketilen yabani otlar kullanım kısımları ve şekilleri

\begin{tabular}{|c|c|c|}
\hline Yöresel Adı & Kullanılan Kısmı & Kullanım Şekli \\
\hline Civcilik & Taze yaprakları & $\begin{array}{l}\text { Genel olarak yardımcı yemek olarak tüketilmektedir. Yoğurtlu salatası, } \\
\text { soğanlı, bulgurlu, pirinçli veya yarmalı şeklide yemeği ya da ıspanak ile } \\
\text { karıştırılıp baharatlarla yemeği yapılmaktadır. }\end{array}$ \\
\hline Ebegümeci & $\begin{array}{l}\text { Taze yaprakları ve } \\
\text { küçük sapları }\end{array}$ & $\begin{array}{l}\text { Haşlama, soğanlı kavurma ve bölgede yetişen diğer otlarla karışık olarak, } \\
\text { kırık buğday ile pişirme şeklinde tüketimi yapılmaktadır. }\end{array}$ \\
\hline Efelek & Yaprakları & $\begin{array}{l}\text { En fazla tüketim yapraklarından sarma yapılması şeklindedir. Ayrıca } \\
\text { yaprakların haşlandıktan sonra kavrulduğu, yoğurtlama şeklinde, bölgede } \\
\text { yetişmekte olan diğger otlarla karıştırılarak veya yarma veya buğday kırığı ile } \\
\text { soğanlı olarak pişirilmektedir. }\end{array}$ \\
\hline Hindiba & $\begin{array}{l}\text { Kök boğazı } \\
\text { üzerinden yapraklar }\end{array}$ & Yapraklar haşlanarak, soğanlı yemeği yapılmaktadır. \\
\hline Isirgan & Taze yapraklar & $\begin{array}{l}\text { Isırganın taze yaprakları firınlarda kurutulmuş buğday unu ile karıştırılarak } \\
\text { yağda kavrulması yapılmaktadır. Çorba ve haşlama şeklinde, kurutulup çay } \\
\text { şeklinde tüketilmektedir. Yapraklarının suyu kaynatılıp } 3 \text { gün kadar ayazda } \\
\text { bekletildikten sonra balla karıştırılıp sabah ve akşamları içilmektedir. }\end{array}$ \\
\hline $\begin{array}{l}\text { Kaldırık } \\
\text { Galdirik }\end{array}$ & $\begin{array}{l}\text { Taze yaprakları, } \\
\text { çiçeği ve yaprak } \\
\text { sapları }\end{array}$ & $\begin{array}{l}\text { Yaprakları ile yumurtalı kavurma, fasulye ya da dövülmüş ceviz ile yemek, } \\
\text { mısır yarması ile sarma, cacık ve yaprak sapları ile de turşu yapılmaktadır. }\end{array}$ \\
\hline $\begin{array}{l}\text { Kazayağ1 } \\
\text { Gazyek }\end{array}$ & Taze yaprakları & $\begin{array}{l}\text { Yaprakları ile yumurtalı veya yumurtasız kavurma, bulgur veya yarma ile } \\
\text { sulu yemek, soğanlı ya da soğansız olarak haşlama, mıllama, yeşil soğan, } \\
\text { peynir ya da çökelek ile karıştırılıp börek iç malzemesi, turşu kurarak ve } \\
\text { yoğurtlu sirkeli salata yapılarak tüketimi yapılmaktadır. }\end{array}$ \\
\hline $\begin{array}{l}\text { Kırçan } \\
\text { Melocan }\end{array}$ & Taze sürgünler & $\begin{array}{l}\text { Sürgünleri unlu-yumurtalı kavurma şeklinde, börek iç malzemesi olarak, } \\
\text { haşlama yapılarak, sarımsaklı yoğurtlu kavurma şeklinde ve turşu yapılarak } \\
\text { tüketilmektedir. }\end{array}$ \\
\hline Medik & $\begin{array}{l}\text { Kök boğazı } \\
\text { üzerindeki } \\
\text { yapraklar }\end{array}$ & Taze yapraklarından limonlu-sirkeli salatalar hazırlanmaktadır. \\
\hline Mendek & $\begin{array}{l}\text { Taze yapraklar ve } \\
\text { küçük yaprak } \\
\text { sapları }\end{array}$ & $\begin{array}{l}\text { Kök boğazı üzerinden kopartılan yapraklardan haşlama veya kavurma } \\
\text { yapılmaktadır. }\end{array}$ \\
\hline Nivik & Taze yapraklar & $\begin{array}{l}\text { Sulu, soğanlı yemeği yapıldığı ve kırık buğday ile pişirildiği, yörede } \\
\text { tüketimi yapılan acuk pekmezi, ekşi erik karığı gibi ekşili ürünler ile birlikte } \\
\text { tüketilmektedir. }\end{array}$ \\
\hline $\begin{array}{l}\text { Sakarca, } \\
\text { Kuzguncuk } \\
\text { soğanı }\end{array}$ & Soğan kısmı & Soğanları unla kızartılarak veya kavurma şeklinde de tüketilmektedir. \\
\hline $\begin{array}{l}\text { Sirken,Hoşkıran } \\
\text { pancarı }\end{array}$ & $\begin{array}{l}\text { Taze yapraklar ve } \\
\text { yaprak sapları }\end{array}$ & $\begin{array}{l}\text { Sirken bitkisinin yaprakları kavrularak, yarma ya da bulgurla pişirilerek } \\
\text { üzerine sarımsaklı yoğurt dökülerek, kavurulduktan sonra un ile kaplanarak } \\
\text { kızartma yapılarak ve pırasa ile birlikte haşlanıp yemeğinin yapılması } \\
\text { şeklinde tüketilmektedir. }\end{array}$ \\
\hline Taykuyruğu & Yaprakları & Yapraklar kurutularak kaynatılıp çay olarak tüketilmektedir. \\
\hline
\end{tabular}

Tay kuyruğu (Equisetum arvense L.) $50 \mathrm{~cm}$ yüksekliğe kadar boylanabilen çok yıllık, rizomlu otsu bir bitkidir. Tahrip edilmiş alanlar ile su kenarlarını habitat olarak tercih ederler (Anonim, 
2016). Yöre halkı tarafından pek kullanılmayan bu bitkinin yapılan araştırmalarda birçok hastalığın tedavisinde kullanıldığı tespit edilmiştir. Toprak üstü kısımlarının kurutularak sıcak su ile demlenip içilmesi başta idrar yolları rahatsızlıkları, bademcik iltihabı gibi bir çok hastalığa iyi geldiği tespit edilmiştir (Saraç ve ark., 2013). Ayrıca Egzama, çıban, kepek önleyici olarak kullanıldığı tespit edilmiştir (Kökçü ve ark., 2015).

Civcilik (Stellaria media subsp. media L.) bitkisi 10-40 cm yüksekliğe kadar boylanabilen tek yıllık, otsu bir bitkidir. Yaprakları karşılıklı ve hemen hemen sapsızdır. Çiçekleri dalların uçlarında oluşur, küçük ve beyaz renklidirler. Civcilik bitkisine yol kenarları, duvar dipleri ve bahçelerde bol miktarda rastlanmaktadır (Baytop, 1999). Yardımcı yemek olarak tüketilmektedir. Yoğurtlu salatası, soğanlı, bulgurlu, pirinçli veya yarmalı şeklide yemeği ya da ıspanak ile karıştırılıp baharatlarla yemeği yapılmaktadır (Demir, 2017). Kaynatılıp, süzülerek içilen civcilik, mide ülseri ve kabızlık rahatsızlıklarına iyi gelmektedir (Akyol ve ark., 2013).

Ebegümeci (Alcea apterocarpa Boıss.) çok yıllık, otsu bir bitkidir. Bitkinin gövdesi çok dallı ve yaprakları uzun saplıdır. Habitatı, maki ve tarlalardır. Endemik özellik göstermektedir (Anonim, 2016). Bitkinin hasatı kök üzerinden yaprak sapları ile birlikte yapıldığı ve yöre halkı ile yapılan görüşmelerde ebegümeci yapraklarının haşlama, soğanlı kavurma ve bölgede yetişen diğer otlarla karışık olarak, kırık buğday ile pişirme şeklinde tüketiminin yapıldığı saptanmıştır. (Demir, 2017). Öksürük giderici olarak yöre halkının kullandığı tespit edilmiştir.

Efelek (Rumex crispus L.) çok y1llık kuvvetli veya dik olarak yetişen $50-150 \mathrm{~cm}$ boyuna gelebilen bir bitkidir. İşlenmiş ve terk edilmiş arazilerde, su kenarlarında, kötü kullanılmış çayırlarda yaygındır. İstilacı bir bitkidir. 2 veya 3 yıllık, otsu bir bitkidir (Serin, 2008). Endemik değildir (Anonim, 2016). Genellikle kök boğazından yaprak sapları ile birlikte hasat edilmektedir. Hasat yapılan yerdeki yöre halkından edinilen bilgilere göre efelek bitkisinin kullanımının en fazla yapraklarından sarma yapıldığı şeklinde olduğu belirlenmiştir. Bunun yanında haşlandıktan sonra kavurmasının yapıldığı, yoğurtla birlikte tüketildiği, bölgede yetişmekte olan diğer otlarla karışık olarak pişirildiği veya yarma veya buğday kırığı ile soğanlı olarak pişirildiği saptanmıştır. Böbrek enfeksiyonuna, jinekolojik hastalıkları, iç hastalıkları, şeker hastalığına karşı tedavi amaçlı kullnılmaktadır (Özgen ve ark., 2012).

Hindiba (Taraxacum buttleri Van Soest), çok yıllık, otsu bir bitkidir. Yol kenarları, tarla ve kayalık alanları habitat olarak tercih ederler. Endemik değildir (Anonim, 2016). Kök boğazı üzerinden hasat edilmekte ve yaprakları tüketilmektedir. Yöre halkından edinilen bilgilere göre yapraklarının haşlama yapılarak, soğanlı yemeğinin yapılmasıyla tüketildiği belirlenmiştir. Safra akışını kolaylaştırıcı, kabızlığı giderici, kuvvetlendirici, temizleyici özelliklere sahiptir. Şeker hastalığına iyi gelmektedir (Baytop, 1999). Bitkinin içerdiği süt derideki nasır ve siğillerin giderilmesinde çok etkilidir. Çiçeklerinden elde edilen destile su ise derilerin temizlenmesinde ve 
özellikle derideki çillerin giderilmesinde kullanılır. Sütü safra kesesi ve mesane taşlarını eritici özelliktedir aynı zamanda mesane iltihaplarına karşı çok etkilidir (Baytop, 1999).

Isırgan (Urtica dioica L.), çok y1llık, otsu bir bitki olup 30-150 cm kadar boylanabilmektedir. Geniş bir yayılış alanına sahiptir. Orman açıklıkları, kayalık-taşlık alanlar ve ırmak kenarları ile bahçelerde sıkça rastlanan bu tür istilacı gurubunda yer almaktadır (Serin, 2008). Endemik değildir (Anonim, 2016). Yöre halkından edinilen bilgilere göre 1sırgan bitkisinin taze yapraklarının fırınlarda kurutulmuş buğday unu ile karıştırılarak yağda kavrulması şeklinde çorbası yapılarak, haşlamasının yapılması ve kurutulup çay olarak tüketiminin olduğu belirlenmiştir. Ayrıca soğuk algınlığı ve öksürüğün doğal tedavisi için, suyunun kaynatılıp 3 gün kadar ayazda bekletildikten sonra balla karıştırılıp sabah ve akşamları içilebildiği tespit edilmiştir. Bunun yanı sıra birçok hastalığın tedavisinde kullanılmaktadır. Bu hastalıkların başında; romatizma, böbrek taşı, kanser, guatr, hemoroit, üriner sistem enfeksiyonları, mide rahatsızlıkları, bronşit, hipertansiyon, infertilite (kadınlar için), mide ağrısı ve gastrik ülser gibi hastalıkların tedavisinde kullanılmaktadır (Özgen ve ark., 2012).

Kaldırık (Trachystemon orientalis L.) bitkisi yörede kaldırayak ya da galdirik olarak isimlendirilmektedir. Çok yıllık ve otsu olup, seyrek geriye dönük, dik tüylü, rizomlu gövdeye sahiptir. Kayın ormanları, nehir kenarları, nemli derin ve dar vadilerde 50-400 rakımlarda yetişmektedir (Serin, 2008). Endemik değildir (Anonim, 2016). Hasat edilen bölgedeki yöre halk1 ile yapılan görüşmelerde kaldırık bitkisinin taze rizomları ile birlikte hasat edildiği ve yaprak, yaprak sapı ve çiçeklerinin ayrı ayrı ya da birlikte tüketilebildiği belirlenmiştir. Çiçeklerinin taze olduğu dönemde yine taze yaprakları ile birlikte yumurtalı kavurma, fasulyeli ya da dövülmüş ceviz ile yemeği yapılmaktadır. Ayrıca yapraklarından mısır yarması ile sarma yapıldığı, cacık yapımında kullanıldığı, yaprak saplarının da turşu olarak değerlendirildiği belirlenmiştir. İdrar arttırıcı olarak kullanılmasının yanında bağırsak rahatsızlarını tedavi edici olarak kullanılmaktadır (Saraç ve ark., 2013).

Kazayağı (Oenanthe pimpinelloides L.) bitkisi, Salıpazarı ilçe ve köylerinde çoğunlukla gazyek ismi ile bilinmektedir. Çok yıllık, otsu bir bitkidir. Endemik bitki değildir (Anonim, 2016). Yöre halkı kazayağı bitkisini en taze ve boylanmamış olduğu dönemde bıçakla kök boğazından kesilerek hasatı yapılmaktadır. Yapraklarının yumurtalı veya yumurtasız kavurmasının yapıldı̆̆ı, bulgur veya yarma ile sulu yemeğinin yapıldığı soğanlı ya da soğansız olarak haşlanması şeklinde, mıhlama yapılarak, yeşil soğan, peynir ya da çökelek ile karıştırılıp börek iç malzemesi yapıldı̆̆g, turşu kurarak ve yoğurtlu sirkeli salata halinde tüketildiği saptanmıştır. Antibiyotik ve analjezik özelliklere sahiptirler (Genç ve Özhatay, 2006).

Kırçan (Smilax excelsa L.), çok yıllık, tırmanıc1-dikenli-çalı formunda ve istilacı olan bir türdür. 0-800 m yükseltilerde ormanlık ve çalılık alanlarda yayılım göstermektedir. Mayıs-Temmuz 
ayında çiçeklenen kırçan, bezelye iriliğinde salkımsı meyvelere sahiptir. Meyveler olgunlaştığında, koyu kırmızı rengindedir (Serin, 2008). Endemik değildir (Anonim, 2016). Kırçan bitkisinin taze uç sürgünlerinin tüketildiği belirlenmiştir. Tüketim şeklinin; çoğunlukla unlu-yumurtalı kavurma şeklinde, börek iç malzemesi olarak, haşlama yapılarak, sarımsaklı yoğurtlu kavurma şeklinde olduğu ve turşu şeklinde olduğu tespit edilmiştir. Özellikle meyvesinin beyin hücrelerinin yenilenmesini sağladığı tespit edilmiştir (Saraç ve ark., 2013)

Medik (Capsella bursa-pastoris L.) tek veya iki yıllık, otsu, 50-60 cm kadar boylanabilen bir bitkidir. Alt yaprakları düzensiz parçalı veya basit, çiçekleri küçük beyaz veya pembe, meyveleri üç köşeli, basıktır (Serin, 2008). Kurak olmayan bölgelerde, yol kıyılarında, çimenliklerde ve bahçe çimlerinin arasında yetişir (Eröztürk, 2004). Endemik değildir (Anonim, 2016). Bitkinin kolay sökülen kökleri ile birlikte hasat edildiği ve taze yapraklarının limonlu-sirkeli salata şeklinde tüketildiği belirlenmiştir. Kahvaltıdan önce balla demlendirilerek tüketildiğinde, böbrek rahatsızlıkları, bronşite iyi gelmektedir (Genç ve Özhatay, 2006)

Mendek (Aegopodium podagraria L.), çok yıllık ve otsu formda bir bitkidir. Salıpazarı ilçesi Koruluk alanları habitat olarak tercih eder. Endemik değildir (Anonim, 2016). Hasat edilen bölgedeki yöre halkı ile yapılan görüşmelerde bitkinin taze olduğu dönemlerde yapraklarının kök boğazı üzerinden kopartıldığı ve haşlama veya kavurma şeklinde tüketildiği belirlenmiştir. Gut ve eklem rahatsızlıklarında kullanılmaktadır (Duke ve ark., 2002).

Nivik (Arum italicum Miller), çok y1llık ve otsu formda bir bitkidir. Habitatı; çalılıklar arası ve koyaklardır. Endemik özellik göstermez (Anonim, 2016). Nivik yapraklarının kök boğazı üzerinden kopartıldığı ve genel olarak sulu yemeğinin, soğanlı ve kırık buğday ile pişirildiği ya da yörede tüketimi yapılan acuk pekmezi, ekşi erik karığı gibi ekşili ürünler ile birlikte hazırlandığı ve bu şekilde tüketildiği belirlenmiştir. Hemoroit, kadın hastalıkları, kanser, ülser ve hemoroid tedavisinde kullanıldığı tespit edilmiştir (Genç ve Özhatay, 2006).

Sakarca (Ornithogalum sigmoideum Freyn et. Sint.) bitkisi 20-30 cm yükselebilen çok yıllık ve otsu bir bitkidir. Yörede kuzguncuk soğanı olarak da bilinmektedir. Endemik özellik göstermemektedir. Ormanlık ve çayırlık alanları habitat olarak tercih ederler (Anonim, 2016). Hasat edilen bölgedeki yöre halkı ile yapılan görüşmelerde bitkinin çoğunlukla soğan kısmının tüketildiği ve genellikle unla kızartma ya da kavurma şeklinde de tüketildiği tespit edilmiştir. Ayrıca yaprak ve çiçekleri sebze olarak tüketilir (Arslanoğlu ve Yalçın, 2009; Kızılarslan and Özhatay, 2012). Birçok hastalığın tedavisinde kullanılan sakarca özellikle sinir hastalıkları, müshil kalp spazmı ve kalp düzenleyici ve koruyucu olarak kullanıldığı tespit edilmiştir (Sargın ve ark., 2013; Thaler ve ark., 2009; Baytop, 1999).

Sirken (Amaranthus retroflexus L.), tek y1llı, yükselici, dik gelişen ve otsu formda olan bir türdür ve 15-100 cm arasında boylanabilmektedir. Yol kenarları ve kültür yapılan alanlarda bulunur 
(Serin, 2008). Endemik değildir (Anonim, 2016). Yöre halk1 ile yapılan görüşmelerde bitkinin kavurmasının yapıldığı, yarma ya da bulgurla pişirilerek üzerine sarımsaklı yoğurt dökülerek tüketildiği, kavurulduktan sonra un ile kaplanarak kızartmasının yapılarak ve pırasa ile birlikte haşlanıp yemeğinin yapılması şeklinde tüketim şekillerinin olduğu belirlenmiştir. Romatizma tedavisinde kullanılkmaktadır (De Natale ve Pollio, 2007).

Samsun ilinde yapılan benzer konulu araştırma sonuçlarına bakıldığında yabani bitkilerin hasat olgunluğuna geldikleri dönemlerin birbiri ile benzeştiği ve yakın zamanlara denk geldiği görülmektedir (Civelek, 2011). Çalışmamızda ele alınan Mendek (Aegopodium podagraria L.) bitkisi Salıpazarı'nda Nisan-Mayıs aylarında hasat olgunluğundayken Civelek (2011) tarafindan yapılan çalışmada aynı bitkinin Bafra'da bu olgunluğa Haziran ayına denk geldiği tespit edilmiştir. Aynı çalışma ile bitkilerin çiçeklenme zamanları karşılaştırıldı̆̆ında efelek bitkisinin aynı dönemlerde çiçeklendiği tespit edilmiştir. Kaldırık (Trachystemon orientalis L.) bitkisinin ise lokasyona göre değişmekle birlikte yaklaşık aynı zamanlarda veya Salıpazarı'nda daha erken çiçeklendiği (Nisan-Mayıs) gözlemlenmiştir.

Kaya ve ark. (2004), Ege Bölgesi’nde sebze olarak tüketilen yabani kuşkonmaz, sirken, yabani hindiba, rezene, gelincik, çobandeğneği ve ebegümecinin içeriklerini ortaya koymak amacıyla yaptıkları çalışmalarda; yabani bitkilerdeki demir, bakır, çinko ve mangan seviyelerini kültür bitkilerine göre daha yüksek tespit etmişlerdir.

Şekeroğlu ve ark. (2005) Ordu ve çevresinde doğadan toplanıp sebze olarak kullanılan ve yörede yoğun bir şekilde tüketilen bazı yabani bitki türlerini, besin değeri bakımından inceleyen çalışmalarında bu bitkilerin mineral madde konsantrasyonları ve besin değeri yönünden geleneksel sebze bitkilerinden daha zengin olduğu tespit etmişlerdir.

\section{Sonuçlar ve Öneriler}

Yürütmüş olduğumuz bu çalışmalar Salıpazarı ilçesinde yapılan ilk çalışma olası nedeniyle İlçede bulunan yenilebilir otlarla ilgili bir envanter niteliğindedir. Ayrıca 12 farklı familya ait bitki türünün yenilebilir ve tıbbi öneme sahip olması alanın hem bitki çeşitliliği hem de etnobotanik özellikler bakımından çeşitli olduğunu göstermektedir. Bununla birlikte Brassicaceae familyasına ait olan Capsella bursa-pastoris L. türünün fitoremediasyon çalışmalarında hiperakümülatör bitki olarak kullanıldığı düşünüldüğünde bazı yenilebilir ve tıbbi bitkilerin daha çok önem kazandığı görülmektedir. Sonuç olarak, bitki çeşitliliğinin yüksek olduğu yurdumuzda bu tür etnobotanik çalışmalarının yapılması, çeşitli yörelerdeki kültürlerimizin ortaya konulması son derece önemlidir.

Çalışmamız ile özellikle kullanımları saptanan sebze olarak tüketilen yabani bitkiler; ekonomik açıdan hem yöre insanlarına hem de ülkemize değerli katkılar sağlayabilecektir. Bitki 
kullanımı bilgilerinin kaydedilerek envanterinin oluşturulması ile Salıpazarı ilçesinin zenginliği ortaya konulmuştur.

\section{Kaynaklar}

Altay, V. ve Karahan, F. (2012). Tayfur Sökmen Kampüsü (Antakya-Hatay) ve çevresinde bulunan bitkiler üzerine etnobotanik bir araştırma. Karadeniz Fen Bilimleri Dergisi, 2(7), 13-28.

Anonim (2015). http://tr.wikipedia.org/wiki/Sal\%C4\%B1pazar\%C4\%B1

Anonim (2016). http://www.tubives.com

Arslanoğlu, F. and Yalçın, T. (2009). The concumption of some plants gathered from nature in Eastern Black Sea Region. VIII Field Crops Congress (pp. 2469-253). Hatay,Turkey.

Balkaya, A. ve Yanmaz, R. (2001). Bitki genetik kaynaklarının muhafaza imkânları ve tohum gen bankalarının çalışma prensipleri. Çevre Koruma Dergisi, 10(39), 25-30.

Baytop, T. (1999). Türkiye'de bitkiler ile tedavi (2. Bask1). İstanbul: Nobel Yayınevi.

Civelek, C. (2011). Bafra Ovası'nda sebze olarak kullanılan yabani bitkilerin toplanmasi, bazı besin içeriklerinin saptanması ve ıslah amaçlı olarak değerlendirilmesi. Yüksek Lisans Tezi, Ondokuz Mayıs Üniversitesi, Fen Bilimleri Enstitüsü, Samsun.

Davis, P. H. (1965-1985). Flora of Turkey and the East Aegean Islands (Vols. 1-9). Edinburgh: Edinburgh University Press.

Davis, P. H., Mill, R. R., Tan, K. (1988). Flora of Turkey and the East Aegean Islands (Vol. 10). Edinburgh: Edinburgh University Press.

Demir, (2017). Salıpazarı İlçesinde sebze olarak tüketilen yabani bitkilerin toplanması ve tanımlanması. Yüksek Lisans Tezi, Ondokuz Mayıs Üniversitesi, Fen Bilimleri Enstitüsü, Samsun.

Duke, J. A., Bogenschutz-Godwin, M. J., du Cellier, J., Duke, P. A. K., (2002). Handbook of medicinal herbs (2nd ed.). Florida: CRC Press LLC.

Eröztürk, N, (2004). Tanrının sağllk bahçesi (3. Baskı). İstanbul: Anahtar Kitaplar Yayınevi.

Faydaoğlu, E. ve Sürücüoğlu, M. S. (2011). Geçmişten günümüze tıbbi ve aromatik bitkilerin kullanılması ve ekonomik önemi. Kastamonu Üniversitesi Orman Fakültesi Dergisi 11(1), 52-67.

Genç, G. E., and Özhatay, N. (2006). An ethnobotanical study in Çatalca (European part of İstanbul) II. Turkish Journal of Pharmaceutical Sciences, 3(2), 73-89.

Güner, A. (2012). Türkiye bitkileri listesi (Damarl bitkiler). İstanbul: ANG Vakfi.

Güner, A., Özhatay, N., Ekim, T., Başer, K. H. C. (2000). Flora of Turkey and the East Aegean Islands ( Vol. 11). Edinburgh: Edinburgh University Press.

Kargığlu, M., Cenkci, S., Serteser, A., Evliyaoğlu, N., Konuk, Kök, M. Ş., Bağcı, Y. (2008). An ethnobotanical survey of Inner-West Anatolia, Turkey. Human Ecology, 36(5), 763-777.

Kaya, İ. ve İncekara, N. (2000). Ege Bölgesi'nde yiyecek olarak kullanılan bazı yabancı otların bileşimi. Türkiye Herboloji Dergisi, 3(2), 56-64.

Kaya, İ., İncekara, N., Nemli, Y. (2004). Ege Bölgesi'nde sebze olarak tüketilen yabani kuşkonmaz, sirken, yabani hindiba, rezene, gelincik, çoban değneği ve ebegümecinin bazı kimyasal analizleri. Yüzüncü Yıl Üniversitesi Ziraat Fakültesi Tarım Bilimleri Dergisi, 14(1), 1-6.

Kızılarslan, Ç. and Özhatay, N. (2012) An ethnobotanical study of the useful and edible plants of İzmit. Marmara Pharmaceutical Journal, 16, 194-200.

Kibar, B. ve Temel, S. (2015). Evaluation of Mineral Composition of Some Wild Edible Plants Growing in the Eastern Anatolia Region Grasslands of Turkey and Consumed as Vegetable. Journal of Food Processing and Preservation, 40, 56-66.

Kökçü, B., Esen, O. and Uysal, İ. (2008). Medicinal plants sold in Çanakkale/Turkey city center herbalists. Biological Diversity and Conservation, 8(3), 80-91.

Kutbay, H. G., Sürmen, B., Kılıç, D. D. ve İmamoğlu, A. (2014). The determination of rare species and risk categories in Nebyan Mountain (Samsun/Turkey). Biological Diversity and Conservation, 7(2), 73-77.

Lyimo, M., Temu, R. P. C. and Mugula, J. K. (2003). Identification and nutrient composition of Indigenous vegetables of Tanzania. Plant Foods Human Nutrition, 58, 82-92.

De Natale, A. and Pollio, A. (2007). Plants species in the folk medicine of Montecorvino Rovella (inland Campania, Italy). Journal of Ethnopharmacology, 109(2), 295-303. 
Özgen, U., Kaya, Y. \& Houghton, P. (2012). Folk medicines in the villages of Ilica District (Erzurum, Turkey). Turkish Journal of Biology, 36(1), 93-106.

Özgen, U., Kaya, Y. \& Coşkun, M. (2004). Ethnobotanical studies in the villages of the district of Ilica (Province Erzurum), Turkey. Economic Botany 58(4), 691-696.

Saraç, D. U., Özkan, Z. C. \& Akbulut, S. (2013). Ethnobotanic features of Rize/Turkey province. Biological Diversity and Conservation, 6(3), 57-66.

Sargın, S. A, Selvi, S., Akçiçek, E. (2013) Investigations of Ethnobotanical aspect of Some Geophytes Growing in Alaşehir (Manisa) and Surrounding Area. Erciyes University Journal of the Institute of Science and Technology, 29(2),170-177.

Serin, Y. (2008). Türkiye'nin çayır ve mera bitkileri. Ankara: Tarım ve Köyişleri Bakanlığı Tarımsal Üretim ve Geliştirme Genel Müd. Yayınları.

Satıl, F., Akçiçek, E. ve Selvi, S. (2008). Madra Dağı ve çevresinde etnobotanik bir çalışma. Biyoloji Bilimleri Araştırma Dergisi 1(1), 31-36.

Şekeroğlu, N., Özkutlu, F., Deveci, M., Dede, O. \&Yılmaz, N. (2005). Evaluation of some wild plants aspect of their nutritional values used as vegetable in Eastern Black Sea Region of Turkey. Asian Journal of Plant Sciences, 5(2), 185-189.

Thaler, K., Kaminski, A., Chapman, A., Langley T., Gartlehner G. (2009) Bach flower remedies for psychological problems and pain: a systematic review. Complementary and Alternative Medicine, 9(1), 16.

Yücel, E., Güney, F. ve Yücel Şengün, İ. (2011). The wild plants consumed as a food in Mihaliççık district (Eskişehir/Turkey) and consumption forms of these plants. Biological Diversity and Conservation, 3(3),158-175. 